\title{
Chinese Secondary EFL Learners' and Teachers' Preferences for Types of Written Corrective Feedback
}

\author{
Haishan $\mathrm{Li}^{1}$ \& Qingshun $\mathrm{He}^{2}$ \\ ${ }^{1}$ Faculty of Humanities and Social Sciences, The University of Queensland, Queensland, Australia \\ ${ }^{2}$ Faculty of English Language and Culture, Guangdong University of Foreign Studies, Guangzhou, China \\ Correspondence: Haishan Li, Faculty of Humanities and Social Sciences, The University of Queensland, St \\ Lucia Campus, Brisbane, QLD 4072, Australia. Tel: 61-040-667-1268. E-mail: haishan.li@uq.net.au
}

\author{
Received: January 2, 2017 Accepted: February 4, 2017 Online Published: February 6, 2017 \\ doi: 10.5539/elt.v10n3p63 URL: http://doi.org/10.5539/elt.v10n3p63
}

\begin{abstract}
How learners perceive written corrective feedback (CF) associates with its effectiveness in language learning. This research investigates students' preferences for three types of written CF, i.e., direct, indirect and metalinguistic written $\mathrm{CF}$, and explores the factors that encourage the teachers to employ these CFs in teaching practice. The findings include: (1) indirect written CF is preferred by most Chinese secondary EFL learners and there exist significant differences among their preferences, (2) gender difference significantly influences learners' preference for metalinguistic written $\mathrm{CF}$ and proficiency differences significantly influence their preference for indirect written CF, (3) indirect written CF is most commonly used by the teachers of secondary levels and (4) there are no significant differences between learners' preferences and teachers' practice in Chinese secondary schools. This research thus presents a new acquaintance with learners' preferences and teachers' justification for their execution.
\end{abstract}

Keywords: Chinese secondary EFL learners, learners' preferences, teachers' practice, written corrective feedback

\section{Introduction}

Errors are unavoidable in the process of learning a foreign language and it is inevitable for the teachers as primary instructors to respond to the learners' erroneous or improper language productions. Corrective feedback (CF) or error correction is defined as "responses to learner utterances that contain an error" (Ellis \& Shitani, 2014, p. 249), either oral or written. There are three basic types of written CF, viz., direct, indirect and metalinguistic written CF. Direct written CF refers to the explicit provision of correct target language forms, indirect written $\mathrm{CF}$, the feedback that serves as an indication to the committed errors, and the metalinguistic written $\mathrm{CF}$, the provision of metalinguistic clues to the nature of errors.

Little attention has been paid to the influential elements of students' preferences and the comparison between students' preferences and the teachers' practice. To enrich written CF literature, this research is to investigate Chinese secondary EFL learners' preferences for and teachers' use of types of written CF. For this purpose, this research is intended to answer the following three questions: (1) What is Chinese secondary EFL learners' most preferable type of written CF? (2) Are the preferable types of written CF influenced by gender and language proficiency? (3) What types of written CF are usually used by Chinese teachers of secondary schools and why do they choose to use them? The layout of this research is as follows. Relevant researches of written CF are reviewed in Section 2. Section 3 is the methodology of this research. The findings of the research will be presented in Section 4. Section 5 is devoted to a discussion of the research findings.

\section{Literature Review}

\subsection{Types of Written $C F$}

Controversial arguments have been brought up on whether written CF is effective or not. CF as negative feedback can be a detrimental factor on learners' mastery of grammar (Vigil \& Oller, 1976), and grammar error correction is ineffective and harmful to learners' writing (Truscott, 1996). This triggers the expansion of research on examining the usefulness of written CF. Based on the comparison between learners with and without written CF treatment, research (e.g. Chandler, 2003; Bitchener et al., 2005; Bitchener, 2008; Bitchener \& Knoch, 2008) 
shows that learners who receive written $\mathrm{CF}$ in targeted linguistic features have better performance in their new pieces of writing than those who do not. Comprehensive error correction can also promote learners' written accuracy and contribute to the development of long-term accuracy (Van Beuningen et al., 2012). Truscott (2007) who has been in support of abandoning written CF restates that "the best estimate is that correction has a small harmful effect on students' ability to write accuracy".

Research on written CF has also examined which type (e.g. Chandler, 2003; Storch \& Wigglesworth, 2004; Hosseiny, 2014) and what kind of combination of types is more effective in improving learners' written accuracy (e.g. Bitchener et al., 2005; Sheen, 2007; Bitchener, 2008; Bitchener \& Knoch, 2008). Although empirical studies vary in their investigation of types of treatment techniques, direct and indirect written CF are two principal comparative subjects among them. However, those studies are inconsistent about which type of technique of them is more effective. For example, according to Chandler (2003), there is no significant difference between direct correction and underlining errors, that is, indirect correction, in accuracy improvement, while Storch and Wigglesworth (2004) hold that indirect CF is more effective than direct CF as learners show a higher level of engagement in indirect CF.

As to the combination of feedback treatment, research (e.g. Bitchener \& Knoch, 2005; Sheen, 2007; Bitchener, 2008) shows differences between direct written CF with and without metalinguistic written CF, but does not reach an agreement towards whether this kind of combination can bring about a more favorable effect on learners. For example, Bitchener (2008) finds that students who have received the combination of feedback do not achieve a higher degree of accuracy than those who have only received direct CF, but Sheen (2007) arrives at an opposite result.

Although previous research has not reached a consensus on the comparative results of different types of written $\mathrm{CF}$ in terms of effectiveness, all the three types of written CF have their edges. Direct written CF provides learners sufficient information to cope with complex linguistic errors (e.g. Bichener et al., 2005; Van Beuningen et al., 2012; Hosseiny, 2014; Park et al., 2015). Indirect written CF enables learners to make reflections on their errors that can lead to long-term development (e.g. Bitchener, 2008; Hosseiny, 2014). Self correction can also invoke learners' problem-solving strategies (Lalande, 1982) and expose learners to a thorough form of language processing (Van Beuningen et al., 2012). Metalinguistic written CF can trigger learners' explicit knowledge so as to understand their committed errors (Ellis et al., 2008).

\subsection{Written CF in Teaching Practice}

For teachers, how written CF can be executed to enhance language learning counts most. Learner factors have been suggested to be considered when written CF is provided (Schulz, 1996; Ferris 1999; Lee et al., 2016), for example, learners' proficiency level. Students with higher level of language proficiency are more competent to self-correct their errors (Park et al., 2015). Research conducted in the Chinese context values learner factors that may contribute to the effectiveness of written CF, including learners' use and understanding of teacher feedback (Zhao, 2010), learners' preferences (Chen et al., 2016) and learner differences such as learning motivation (Li \& Li, 2012) and affection (Han \& Hyland, 2015). However, the Chinese EFL learners participating in many studies are at tertiary levels.

Ur (1996) contends that knowing how students would like to be taught should be part of guidance to assure successful teaching. Likewise, knowing students' perceptions on written CF may be a contributing factor on its effectiveness. There are also abundant researches on reporting how learners view written CF (e.g. Lee, 2005; Weaver, 2006; AlHajri \& Al-Mahrooqi, 2013). Ferris (1999) refutes what Truscott (1996) claims by reporting students' positive attitudes towards the necessity of teachers' correction, which is the same as what has been found in the research of AlHajri and Al-Mahrooqi (2013) and Lee (2005). Most student participants in different studies express their preference to be corrected by teachers. Yang (2016) also reports that the Chinese secondary EFL learners believe writing as difficult and they consider the given feedback as an necessary tool to promote their writing ability.

Major (1988) also believes that the success of correction is relevant to teachers' understanding of their students. The incorporation of preferences and needs of language learners can ensure the effectiveness of error correction in classroom practice (Oladejo, 1993). Additionally, investigation on students' perceptions and preferences may contribute to getting a whole picture of how to administer feedback (Guénette, 2007).

Therefore, "teachers should be prepared to vary who, when and how they correct in accordance with the cognitive and affective needs of the individual learner" (Ellis, 2009). One practical element that Truscott (1996) mentions to support his denial of the effectiveness of written CF lies in learners' willingness to use the feedback given by teachers. Students may be more willing to accept the feedback that caters for their preference. Thus 
getting to know what students prefer will contribute to the teaching practice.

\section{Research Design}

\subsection{Participants}

This research includes 111 participants with a student-teacher ratio at about 3:1. There are 84 Chinese EFL learners and 27 teachers. All the learners are currently receiving secondary education, and all the teachers are secondary school English teachers. The ratio of male to female students is 1:1 and that of male to female teachers, around 1:4.

\subsection{Instruments}

There are two questionnaires respectively designed for students and teachers. Five statements are presented in the questionnaire for students (see Appendix A). The first two statements respectively correspond to students' willingness to be corrected (I want teachers to correct my errors in writing) and their preference for the total volume of errors that should be corrected (Teachers should correct all my errors in writing). The other three statements are about learners' preference for receiving direct, indirect and metalinguistic written CF. Examples are attached to the three statements so as to clarify the meaning of each statement.

As to the questionnaire for teachers, there are three statements for teachers to rate their frequent usage of direct, indirect and metalinguistic written CF (see Appendix B). For example, the first statement is I usually provide students the correct forms of their errors when I revise their writing texts. Teachers were asked to write down reasons for their chosen scale of each statement. Examples are also provided to illustrate the differences of the three types of written CF.

All the participants' responses are rated on a five-point Likert scale, with its scoring from 5 indicating strongly agree to 1 indicating strongly disagree (strongly agree $=5$, agree $=4$, undecided $=3$, disagree $=2$ and strongly disagree $=1$ ).

\subsection{Data Collection and Analysis}

Students' responses were collected by a class coordinator who teaches high school freshmen. Students were asked to write down their choice of each statement when the questionnaire was displayed in class by projecting. Differently, teachers' responses were collected by the distribution of paper questionnaire and its online link. The obtained data are analyzed using SPSS 22.0 and besides, qualitative analysis is also conducted on teachers' explanations of their choices.

\section{Findings}

\subsection{Students' Responses}

Table 1 below shows the distribution of students' responses to each statement. As to students' willingness to be corrected, almost $95 \%$ of the participated students strongly agree or agree that they want teachers' correction of their writing. The highest mean score (4.69) also indicates that most students share their willingness to be corrected by teachers. With regard to whether teachers should correct all their errors, over half of the students appreciate teachers' overall feedback, and only a smaller proportion (27.4\%) of students show uncertainty about this statement.

Table 1. Students' responses to statements

\begin{tabular}{lllllll}
\hline Statement & $\mathrm{SA}(\mathrm{n} / \%)$ & $\mathrm{A}(\mathrm{n} / \%)$ & $\mathrm{U}(\mathrm{n} / \%)$ & $\mathrm{D}(\mathrm{n} / \%)$ & $\mathrm{SD}(\mathrm{n} / \%)$ & Mean \\
\hline 1 & $66(78.6 \%)$ & $13(15.5 \%)$ & $3(3.6 \%)$ & $1(1.2 \%)$ & $1(1.2 \%)$ & 4.69 \\
2 & $23(27.4 \%)$ & $26(31 \%)$ & $23(27.4 \%)$ & $3(3.6 \%)$ & $9(10.7)$ & 3.61 \\
3 & $16(19 \%)$ & $12(14.3 \%)$ & $31(36.9 \%)$ & $14(16.7 \%)$ & $11(13.1 \%)$ & 3.10 \\
4 & $47(56 \%)$ & $20(23.8 \%)$ & $10(11.9 \%)$ & $4(4.8 \%)$ & $3(3.6 \%)$ & 4.24 \\
5 & $19(22.6 \%)$ & $18(21.4 \%)$ & $24(28.6 \%)$ & $9(10.7 \%)$ & $14(16.7 \%)$ & 3.23 \\
\hline
\end{tabular}

Note: $\mathrm{SA}=$ strongly agree, $\mathrm{A}=$ agree, $\mathrm{U}=$ undecided, $\mathrm{D}=$ disagree, $\mathrm{SD}=$ strongly disagree.

It can be seen that the majority of respondents hold positive attitude towards written CF from teachers, which becomes the prerequisite for further investigating their preference for types of written CF. The mean scores of 
the last three statements $(3.10,4.24,3.23)$ respectively represent students' average rating of their preference for direct, indirect and metalinguistic written CF. According to the mean scores, indirect written CF is the most popular type among students while direct written CF the least popular. 67 students out of 84 acknowledge that they prefer to receive indirect written $\mathrm{CF}$ from teachers and then correct their errors marked with symbols on their own, with only $11.9 \%$ of students uncertain about their preference for indirect written $\mathrm{CF}$ and $8.4 \%$ of students not considering it as their preferable type. However, when asked about their preference for direct written CF, most students (36.9\%) fall in the scale of undecided, even outnumbering the sum of students who choose the scale of strongly agree (19\%) or agree $(14.3 \%)$. $44 \%$ of students perceive metalinguistic written CF as their preferable type, with a smaller percentage of students unsure of their desire (28.6\%) and their dislike (27.4\%). In all, the proportion of students who show their affection for the three types of written CF reaches more than $30 \%$.

\subsection{Individual Variables}

\subsubsection{Gender}

In order to examine the role of gender difference in students' preferences, the scoring results of students' preferences for the three type of written CF are respectively classified into two groups by gender (see Table 2). As shown in Table 2, the mean scores of the female group (respectively 3.19, 4.29 and 3.55) outweigh those of the male groups (respectively 3.00, 4.29 and 2.90) in terms of their preference to direct, indirect and metalinguistic written CF. Thus it can be seen that the female students prefer to receive all the three types of written CF than their male counterparts. It is also noted that the standard deviations of female students are all smaller than those of male students.

Table 2. Gender Distribution of students' preferences for types of WCF

\begin{tabular}{llllll}
\hline & gender & $\mathrm{N}$ & Mean & Std. Deviation & Std. Error Mean \\
\hline \multirow{2}{*}{ Direct } & Male & 42 & 3.00 & 1.379 & .213 \\
& Female & 42 & 3.19 & 1.153 & .178 \\
\multirow{2}{*}{ Indirect } & Male & 42 & 4.19 & 1.194 & .184 \\
& Female & 42 & 4.29 & .944 & .146 \\
\multirow{2}{*}{ Metalinguistic } & Male & 42 & 2.90 & 1.411 & .218 \\
& Female & 42 & 3.55 & 1.253 & .193 \\
\hline
\end{tabular}

\subsubsection{Students' Language Proficiency}

In this research student participants' language proficiency is determined by their recent mid-term achievement test which examines students' English listening, reading and writing. To some extent the results of this achievement test can reveal students' language proficiency.

The results were divided into five levels, excellent, good, moderate, low and poor (see Table 3 below). The full mark of the test is 150 , and the five levels respectively correspond to above $90 \%, 80 \%$ to $90 \%, 70 \%$ to $80 \%$, $60 \%$ to $70 \%$ and below $60 \%$ of 150 .

Table 3. Students' mid-term achievement test grades

\begin{tabular}{llllll}
\hline & $\begin{array}{l}\text { Excellent } \\
(\geq 135)\end{array}$ & $\begin{array}{l}\text { Good } \\
(120 \sim 135)\end{array}$ & $\begin{array}{l}\text { Moderate } \\
(105 \sim 120)\end{array}$ & $\begin{array}{l}\text { Low } \\
(90 \sim 105)\end{array}$ & $\begin{array}{l}\text { Poor } \\
(<90)\end{array}$ \\
\hline $\mathrm{N}$ & 0 & 31 & 38 & 14 & 1 \\
Percentage (\%) & 0 & 36.9 & 45.2 & 16.7 & 1.2 \\
\hline
\end{tabular}

Table 3 shows that no one gains a score of 135 or higher and there is only one student who fails the test. The majority of students fall in the level of moderate (45.2\%) and a relatively smaller proportion of students (36.9\%) achieve their grades ranging from 120 to 135 . 
Table 4. Preference differences in student groups with different levels of language proficiency

\begin{tabular}{lllll}
\hline & & Mean & Std. Deviation & Std. Error Mean \\
\hline Direct & Excellent & $/$ & $/$ & $/$ \\
& Good & 3.00 & 1.483 & .266 \\
& Moderate & 3.18 & 1.062 & .172 \\
& Low & 3.00 & 1.359 & .363 \\
\multirow{5}{*}{ Indirect } & Poor & 4.00 & $/$ & $/$ \\
& Excellent & $/$ & $/$ & $/$ \\
& Good & 4.10 & 1.221 & .219 \\
& Moderate & 4.34 & .909 & .147 \\
Metalinguistic & .760 & .203 \\
& Low & 4.50 & $/$ & $/$ \\
& Poor & 1.00 & $/$ & .278 \\
& Excellent & $/$ & 1.594 & .209 \\
& Good & 3.00 & 1.288 & .308 \\
& Moderate & 3.26 & 1.151 & $/$ \\
\hline
\end{tabular}

The ratings of their preference for the three types of written CF were grouped by the five levels (see Table 4). There are differences in mean scores among students of different levels. As to students' preference for direct written CF, the mean score of moderate level (3.18) is higher than that of good (3.00) and low level (3.00). The three mean scores are close to 3 , the score of undecided, while the only one student at poor level has higher preference to be provided direct written CF from teachers. Differently, students of low level on average are more desirable to be given indirect and metalinguistic written CF than the other three levels, as the mean scores of the two types of written CF (respectively 4.50 and 3.64) are the highest among the levels.

\subsection{Teachers' Responses}

Table 5 demonstrates the scoring results of the surveyed teachers' responses to whether or not they usually provide students with the three types of written CF. Over $85 \%$ of the teachers admit that indirect written CF is a frequent type of written CF that they mark in students' writing. The mean score (4.04) indicates that indirect written CF is the most common in teachers' practice; it is higher than that of the other two types. In comparison with the mean score of students' preference for indirect written CF (4.24), there exist only small differences. Indirect written $\mathrm{CF}$ becomes not only the students' most preferable type of written $\mathrm{CF}$, but also the type of written $\mathrm{CF}$ that teachers usually provide.

However, more than half teacher respondents feel uncertain about direct and metalinguistic written CF, or deny that they usually provide them. Additionally, according to their mean score of teachers' ratings (respectively 3.22 and 2.96), teachers might provide direct written CF more frequently than metalinguistic written CF while students prefer metalinguistic written CF more than direct written CF.

Table 5. Teachers' responses to statements

\begin{tabular}{lllllll}
\hline Statement & SA & A & U & D & SD & Mean \\
\hline 1 & $4(14.8 \%)$ & $9(33.3 \%)$ & $3(11.1 \%)$ & $11(40.7 \%)$ & $0(0 \%)$ & 3.22 \\
2 & $8(29.6 \%)$ & $15(55.6 \%)$ & $1(3.7 \%)$ & $3(11.1 \%)$ & $0(0 \%)$ & 4.04 \\
3 & $0(0 \%)$ & $10(37 \%)$ & $7(25.9 \%)$ & $9(33.3 \%)$ & $1(3.7 \%)$ & 2.96 \\
\hline
\end{tabular}

Note: $\mathrm{SA}=$ strongly agree, $\mathrm{A}=$ agree, $\mathrm{U}=$ undecided, $\mathrm{D}=$ disagree, $\mathrm{SD}=$ strongly disagree.

Teachers in support of the provision of indirect written CF emphasize the necessity of self correction and its contribution to cultivating students' self-learning and self-thinking ability, and deepening their memory and 
impression of their committed errors and the correct forms. The lack of opportunities for students to self-correct and think by themselves are the principal reasons raised by the teachers who do not advocate the use of direct written CF. But for the counterparts, direct written CF is favorable as students can clearly know where they get wrong and the correct forms provided by teachers, especially for those who are uncertain about or have difficulty in correcting their errors.

It is noted that the surveyed teachers have not reached a consensus on which type of written CF, direct or indirect, should be given to students who are poor in English. Some of them favor the direct one as they are worried about these students' inability to correct their errors, while others insist that these students can also benefit from the process of self-correction.

With regard to metalinguistic written $\mathrm{CF}$, teachers advocate its usefulness as students can know not only how to correct their errors, but also the roots of their errors. Teachers' personal habits and how they perceive metalinguistic written $\mathrm{CF}$ also influence their execution. Two teachers report that they prefer to provide oral metalinguistic CF in class, and some teachers mention that metalinguistic written CF is not necessary and cause problems to their teaching. Waste of time is the main issue. Therefore it can be seen that teachers' negative views on metalinguistic written CF lead to their non-frequent use.

\section{Discussion}

\subsection{On Differences of Students' Preferences for Types of Written CF}

Pair-samples t-tests are taken to examine whether there are significant differences between students' preference for any two types of written CF. See Table 6 below.

Table 6. Paired-samples t-test of types of written CF

\begin{tabular}{lllllll}
\hline & \multicolumn{2}{l}{ Paired Samples Correlations } & \multicolumn{4}{l}{ Paired Samples Test } \\
& $\mathrm{N}$ & Correlation & Sig. & $\mathrm{t}$ & $\mathrm{df}$ & Sig. (2-tailed) \\
\hline Direct - Indirect & 84 & -.319 & .003 & -5.507 & 83 & .000 \\
Direct - Meta- & 84 & .196 & .073 & -.719 & 83 & .474 \\
Indirect - Meta- & 84 & .062 & .578 & 5.512 & 83 & .000 \\
\hline
\end{tabular}

As shown in Table 6 , two of the significant values $(p=.000)$ are smaller than 0.05 , which indicates that significant differences exist between the scoring results of the students' preference for direct and indirect written $\mathrm{CF}$, and between their preference for indirect and metalinguistic written CF. There is no significant difference between students' preference for direct and metalinguistic written CF.

\subsection{On Gender Difference and Levels of Language Proficiency}

Two learner variables, gender and language proficiency, are analyzed to find out whether they will significantly influence students' preference for direct, indirect and metalinguistic written CF by respectively conducting independent t-tests and one-way ANOVA test. See Table 7 and Table 8.

As shown in Table 7, the significant value of students' preference for direct written CF is .494, which means that there is no significant difference between male and female students. Likewise, as the value of .686 is higher than .05 , there is either no significant gender difference in students' preference for indirect written CF. However, there exists significant gender difference in students' preference for metalinguistic written $\mathrm{CF}(\mathrm{p}=.03<.05)$.

Table 7. Independent sample test on gender difference of different types

\begin{tabular}{|c|c|c|c|c|c|c|}
\hline & & \multicolumn{2}{|c|}{$\begin{array}{l}\text { Levene's Test for } \\
\text { Equality of Variances }\end{array}$} & \multicolumn{3}{|c|}{ T-test for Equality of Means } \\
\hline & & $\mathrm{F}$ & Sig. & $\mathrm{t}$ & $\overline{d f}$ & Sig.(two-tailed) \\
\hline Direct & Equal variances assumed & .478 & .491 & -.687 & 82 & .494 \\
\hline Indirect & Equal variances not assumed & 4.544 & .036 & -.405 & 77.864 & .686 \\
\hline Meta- & Equal variances assumed & .139 & .711 & -2.208 & 82 & .030 \\
\hline
\end{tabular}


Table 8. ANOVA test

\begin{tabular}{lllllll}
\hline & & Sum of Squares & df & Mean Square & F & Sig. \\
\hline Direct & Between groups & 1.528 & 3 & .509 & .309 & .819 \\
& Within groups & 131.711 & 80 & 1.646 & & \\
\multirow{5}{*}{ Indirect } & Total & 133.238 & 83 & & & \\
& Between groups & 12.476 & 3 & 4.159 & 4.020 & .010 \\
& Within groups & 82.762 & 80 & 1.035 & & \\
\multirow{3}{*}{ Metalinguistic } & Total & 95.238 & 83 & & & \\
& Between groups & 4.120 & 3 & 1.373 & .730 & .537 \\
& Within groups & 150.583 & 80 & 1.882 & & \\
& Total & 154.702 & 83 & & & \\
\hline
\end{tabular}

One-way ANOVA test is adopted to analyze whether significant differences exist among students of different proficiency levels. Results from Table 8 indicate that students' proficiency levels do significantly influence their preference for indirect written CF with the significant value smaller than $.05(\mathrm{p}=.010)$, but not their preference for direct and metalinguistic written $\mathrm{CF}$ as the corresponding values are both higher than $.05(\mathrm{p}=.819$ and .537 respectively).

\subsection{On Teachers' Statements of Reasons}

In the teachers' explanations of why they usually provide a certain type of written $\mathrm{CF}$, factors that they consider can be mainly classified into four categories, i.e., type-based, student-based, teacher-related and practical factors, with examples of teachers' statements shown in Table 9.

Table 9. Examples of statements of type-based, student-based, teacher-related and practical factors

\begin{tabular}{ll}
\hline Types & Statements of reasons \\
\hline Direct & Students can access to the correct forms of their errors for many times which can \\
strengthen their impression on those errors. (Type-based) \\
I provide students with different types of feedback. For those good students I would just \\
circle their committed errors while for those who are poor in English, I would directly \\
provide them with correct forms. (Student-based) \\
My former English teachers did like this. (Teacher-related) \\
Lapses in verb tense and in expression keep the essay from earning a better grade. \\
(Practical) \\
It provides opportunities for students to self correct their errors. (Type-based) \\
I would provide students the concise forms when they have severe problems with basic \\
English expression. (Student-based) \\
There are too many written texts needed to be revised, and it helps to save time. \\
(Practical) \\
It can not only remind students of their errors, but also examine students' metalinguistic \\
knowledge. (Type-based) \\
It is suitable for students of moderate levels or with confusion of their committed errors. \\
(Student-based) \\
I prefer to provide oral metalinguistic feedback in class. (Teacher-related) \\
Time is limited for revision. (Practical)
\end{tabular}


The reasons that the teachers have mentioned are labeled as type-based when they discussed the characteristics or advantages relevant to enhancing language learning that direct, indirect or metalinguistic written CF have. Student-based factors are about learner variables, such as learners' language proficiency and affection, while teacher-related factors are the aspects of teachers themselves that influence their choice of providing written CF, for example, their personal habits. Practical factors are concerned with real situations that a teacher may confront when they rate students' compositions, like time restriction.

Teachers' statements are grouped by five categories, type-based, student-based, teacher-related, practical and others. Then the number of statements in each category is calculated (see Table 10). Some of teachers' statements belong to more than one category, and thus the total number of statements may reach over 27.

Table 10 shows that most statements lie in the category of type-based, which means teachers value more on type-based factors when they consider whether or not they should execute the three types of written CF in their actual practice. There is a small group of teachers who take students' proficiency levels, needs and affection into consideration. Teacher-related factors also account for an important part among teachers' views on metalinguistic written CF.

Table 10. Number of statements in four categories of factors

\begin{tabular}{llll}
\hline Reasons & Direct $(\mathrm{N})$ & Indirect $(\mathrm{N})$ & Metalinguistic $(\mathrm{N})$ \\
\hline Type-based & 14 & 19 & 9 \\
Student-based & 8 & 7 & 7 \\
Teacher-related & 1 & 0 & 9 \\
Practical & 1 & 1 & 5 \\
others & 3 & 0 & 1 \\
$\mathrm{~N}$ & 28 & 27 & 31 \\
\hline
\end{tabular}

\subsection{On the Difference between Students' Preferences and Teachers' Practice}

Chi-square tests are conducted to examine whether or not there are significant differences between students' preferences and teachers' practice. See Table 11, 12 and 13 below.

Table 11. Chi-Square test of direct written CF

\begin{tabular}{llll}
\hline & Value & df & Asymp. Sig. (two-sided) \\
\hline Pearson Chi-Square & $17.468^{\mathrm{a}}$ & 12 & 0.133 \\
Likelihood Ratio & 19.502 & 12 & 0.077 \\
Linear-by-Linear Association & 0.054 & 1 & 0.816 \\
N of Valid Cases & 27 & & \\
\hline
\end{tabular}

a. 20 cells $(100.0 \%)$ have expected count less than 5 . The minimum expected count is .11 .

Table 12. Chi-Square test of indirect written CF

\begin{tabular}{llll}
\hline & Value & df & Asymp. Sig. (two-sided) \\
\hline Pearson Chi-Square & $9.714^{\mathrm{a}}$ & 12 & .641 \\
Likelihood Ratio & 10.645 & 12 & .560 \\
Linear-by-Linear Association & 1.242 & 1 & .265 \\
N of Valid Cases & 27 & & \\
\hline
\end{tabular}

a. 19 cells $(95.0 \%)$ have expected count less than 5 . The minimum expected count is .04 . 
Table 13. Chi-Square test of metalinguistic written CF

\begin{tabular}{llll}
\hline & Value & df & Asymp. Sig. (two-sided) \\
\hline Pearson Chi-Square & $18.578^{\mathrm{a}}$ & 12 & .099 \\
Likelihood Ratio & 13.672 & 12 & .322 \\
Linear-by-Linear Association & .495 & 1 & .482 \\
N of Valid Cases & 27 & & \\
\hline
\end{tabular}

a. 20 cells $(100.0 \%)$ have expected count less than 5 . The minimum expected count is .07 .

Significant values of Pearson Chi-square indicates that no significant differences exist between students' preferences and teachers' practice in the three types of written $\mathrm{CF}$ as they are all higher than $.05(\mathrm{P}=.133, .641$ and .099 respectively). In other words, there is a match between what students prefer and what teachers usually do.

\section{Conclusion}

This research shed light on three types of written $\mathrm{CF}$, i.e., direct, indirect and metalinguistic written $\mathrm{CF}$ and investigated Chinese secondary EFL learners' preferences for and teachers' practice in them. Data collected from questionnaires show that indirect written $\mathrm{CF}$ is the most popular type among students and teachers and significant differences exist between students' preferences for direct and indirect written CF, and between indirect and metalinguistic written CF. Gender and language proficiency have been verified to exert influence on students' preferences, but not on all the three types of written CF. Gender difference is only significant in their preference for metalinguistic written $\mathrm{CF}$ and students of different proficiency levels also significantly influence their preference for indirect written $\mathrm{CF}$.

With regard to teachers' practice, teachers mainly justify their use by stating profitable features that each type of written CF have in language learning. It is found that there is a fit between what teachers do and what learners prefer in the aspect of types of written CF. This research has enriched the existing literature, complementing research on students' and teachers' perceptions of written $\mathrm{CF}$, and also has implications on teachers' provision of written $\mathrm{CF}$ and teachers' reflections on their teaching practice. However, the number of student and teacher participants is still limited, which may restrict some research areas. For example, due to the limited number of student participants, post-hoc tests cannot be conducted to figure out where significant differences exist in specific groups of students with different proficiency levels. In addition, whether or to what extent the fit of students' preferences and teachers' practice can bring about better outcomes needs further discussion.

\section{Acknowledgements}

This work was supported by China Scholarship Council Trust (201608440155) and a grant from Guangdong University of Foreign Studies (16TS21). The authors are also grateful to Ms. Yifang Chen for help with data collection and HL would like to acknowledge the support provided by Mr. De Li during her study in the University of Queensland.

\section{References}

Al Hajiri, F., \& Al-Mahrooqi, R. (2013). Student perceptions and preferences concerning instructors' corrective feedback. Asian EFL Journal, 70, 28-53.

Bitchener, J. (2008). Evidence in support of written corrective feedback. Journal of Second Language Writing, 17(2), 102-118. http://dx.doi.org/10.1016/j.jslw.2007.11.004

Bitchener, J., \& Knoch, U. (2008). The value of written corrective feedback for migrant and international students. Language Teaching Research, 12(3), 409-431. http://dx.doi.org/10.1177/1362168808089924

Bitchener, J., Young, S., \& Cameron, D. (2005). The effect of different types of corrective feedback on ESL student writing. Journal of Second Language Writing, 14(3), 191-205. http://dx.doi.org/10.1016/j.jslw.2005.08.001

Chandler, J. (2003). The efficacy of various kinds of error feedback for improvement in the accuracy and fluency of student writing. Journal of Second Language Writing, 12(3), 267-296. http://dx.doi.org/10.1016/S1060-3743(03)00038-9 
Chen, S.-B., Nassaji, H., \& Liu, Q. (2016). EFL learners' perceptions and preferences of written corrective feedback: a case study of university students from Mainland China. Asian-Pacific Journal of Second and Foreign Language, 1(5), 1-17. http://dx.doi.org/10.1186/s40862-016-0010-y

Ellis, R. (2009). Corrective feedback and teacher development. L2 Journal, 1(1), 3-18.

Ellis, R., \& Shintani, N. (2014). Exploring language pedagogy through second language acquisition research. Abingdon, Oxon: Routledge.

Ellis, R., Sheen, Y., Murakami, M., \& Takashima, H. (2008). The effects of focused and unfocused written corrective feedback in an English as a foreign language context. System, 36(3), 353-371. http://dx.doi.org/10.1016/j.system.2008.02.001

Ferris, D. (1999). The case for grammar correction in L2 writing classes: a response to Truscott (1996). Journal of Second Language Writing, 8(1), 1-11. http://dx.doi.org/10.1016/S1060-3743(99)80110-6

Guénette, D. (2007). Is feedback pedagogically correct? Research design issues in studies of feedback on writing. Journal of Second Language Writing, 16(1), 40-53. http://dx.doi.org/10.1016/j.jslw.2007.01.001

Han, Y., \& Hyland, F. (2015). Exploring learner engagement with written corrective feedback in a Chinese tertiary EFL classroom. Journal of Second Language Writing, 30, 31-44. http://dx.doi.org/10.1016/j.jslw.2015.08.002

Hosseiny, M. (2014). The role of direct and indirect written corrective feedback in improving Iranian EFL students' writing skill. Procedia - Social and Behavioral Sciences, 98, 668-674. http://dx.doi.org/10.1016/j.sbspro.2014.03.466

Lalande, J. F. (1982). Reducing composition errors: an experiment. Modern Language Journal, 66(2), 140-149. http://dx.doi.org/10.1111/j.1540-4781.1982.tb06973.x

Lee, I. (2005). Error correction in the L2 writing classroom: what do students think?. TESL Canada Journal, 22(2), 1-16. https://doi.org/10.18806/tesl.v22i2.84

Lee, I., Mak, P., \& Burns, A. (2016). EFL teachers' attempts at feedback innovation in the writing classroom. Language Teaching Research, 20(2), 248-269. http://dx.doi.org/10.1177/1362168815581007

Li, S., \& Li, P.-J. (2012). Individual differences in written corrective feedback: a multi-case study. English Language Teaching, 5(11), 38-44. http://dx.doi.org/10.5539/elt.v5n11p38

Major, R. C. (1988). Balancing form and function. International Review of Applied Linguistics in Language Teaching, 26(2), 81-100. http://dx.doi.org/10.1515/iral.1988.26.2.81

Oladejo, J. (1993). Error correction in ESL: learners' preferences. TESL Canada Journal, 10(2), 71-89. https://doi.org/10.18806/tesl.v10i2.619

Park, E. S., Song, S., \& Shin, Y. K. (2016). To what extent do learners benefit from indirect written corrective feedback? A study targeting learners of different proficiency and heritage language status. Language Teaching Research, 20(6), 678-699. http://dx.doi.org/10.1177/1362168815609617

Schulz, R. A. (1996). Focus on form in the foreign language classroom: students' and teachers' views on error correction and the role of grammar. Foreign Language Annals, 29(3), 343-364. http://dx.doi.org/10.1111/j.1944-9720.1996.tb01247.x

Sheen, Y. (2007). The effect of focused written corrective feedback and language aptitude on ESL learners' $\begin{array}{lllll}\text { acquisition of } & \text { articles. }\end{array}$ http://dx.doi.org/10.1002/j.1545-7249.2007.tb00059.x

Storch, N., \& Wigglesworth, G. (2010). Learners' processing, uptake, and retention of corrective feedback on Writing. Studies in Second Language Acquisition, 32(2), 303-334. http://dx.doi.org/10.1017/S0272263109990532

Truscott, J. (1996). The case against grammar correction in L2 writing classes. Language Learning, 46(2), 327-369. http://dx.doi.org/10.1111/j.1467-1770.1996.tb01238.x

Truscott, J. (2007). The effect of error correction on learners' ability to write accurately. Journal of Second Language Writing, 16(4), 255-272. http://dx.doi.org/10.1016/j.jslw.2007.06.003

Ur, P. (1996). A Course in Language Teaching: Practice and Theory. Cambridge: Cambridge University Press.

Van Beuningen, C. G., De Jong, N. H., \& Kuiken, F. (2012). Evidence on the effectiveness of comprehensive 
error correction in second language writing. Language Learning, 62(1), 1-41. http://dx.doi.org/10.1111/j.1467-9922.2011.00674.x

Vigil, N. A., \& Oller, J. W. (1976). Rule fossilization: a tentative model. Language Learning, 26(2), 281-295. http://dx.doi.org/10.1111/j.1467-1770.1976.tb00278.x

Weaver, M. (2006). Do students value feedback? Student perceptions of tutors' written responses. Assessment \& Evaluation in Higher Education, 31(3), 379-394. http://dx.doi.org/10.1080/02602930500353061

Yang, Y.-J. (2016). An investigation of Chinese junior high school teachers' and teachers' attitudes towards EFL writing. International Journal of Research Studies in Education, 5(2), 59-75, http://dx.doi.org/10.5861/ijrse.2015.1209

Zhao, H.-H. (2010). Investigating learners' use and understanding of peer and teacher feedback on writing: a comparative study in a Chinese English writing classroom. Assessing Writing, 15(1), 3-17, http://dx.doi.org/10.1016/j.asw.2010.01.002

\section{Appendix A}

\section{Questionnaire for students}

1. I want teachers to correct my errors in writing.

2. Teachers should correct all my errors in writing.

3. I mostly prefer the way that teachers directly provide me the correct forms of my errors.

4. I mostly prefer the way that teachers just point out my errors by marking symbols (e.g. a cross) and let me self correct the errors.

5. I mostly prefer the way that teachers label the type of my errors and let me self correct the errors.

\section{Appendix B}

\section{Questionnaire for teachers}

1. I usually provide students the correct forms of their errors when I revise their writing texts.

Please state the reasons for your choice.

2. I usually point out students' errors by marking symbols instead of directly providing them the correct forms when I revise their writing texts.

Please state the reasons for your choice.

3. I usually label the type of students' errors when I revise their writing texts.

Please state the reasons for your choice.

\section{Copyrights}

Copyright for this article is retained by the author(s), with first publication rights granted to the journal.

This is an open-access article distributed under the terms and conditions of the Creative Commons Attribution license (http://creativecommons.org/licenses/by/4.0/). 